\title{
EFFICIENCY OF COMBINED USE OF FULLERENE C60 AND BOVINE SERUM ALBUMIN FOR REHABILITATION OF VITRIFIED FRAGMENTS OF RAT IMMATURE SEMINIFEROUS TUBULES
}

\author{
N.O. Volkova", M.S. Yukhta, L.V. Sokil, L.G. Chernyshenko, L.V. Stepanyuk, A.M. Goltsev \\ Institute for Problems of Cryobiology and Cryomedicine of the National Academy of Sciences of Ukraine, Kharkiv, Ukraine \\ *Corresponding author: volkovana781@gmail.com
}

Received 14 Juny 2021; Accepted 6 September 2021

\begin{abstract}
Background. Today, cryopreserved reproductive tissues are used to treat some forms of male infertility. However, after long-term preservation of fragments of seminiferous tubules of testes (FSTT) in a low-temperature bank $\left(-196^{\circ} \mathrm{C}\right)$ their morphological and functional characteristics decrease reversibly. To solve this problem after freezing-thawing, the use of rehabilitation media with special additives is promising. Due to the fact that serum albumin and fullerene $\mathrm{C} 60$ have powerful protective and antioxidant properties, their use allows to stabilize the plasma membrane, osmotic pressure, and reduce free radicals that make them promising candidates to use in the development of rehabilitation media for biological objects after cryopreservation.

Objective. The efficacy of fullerene C60, bovine serum albumin (BSA), and their combination as components of rehabilitation medium of vitrified FSTT of immature rats was studied.

Methods. Vitrified-thawed samples of FSTT were incubated $\left(22^{\circ} \mathrm{C}\right)$ for 30 minutes in Leibovitz's medium

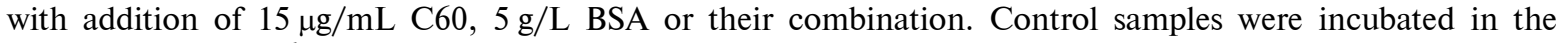
medium without C60 or BSA addition. Metabolic activity (MTT test), histomorphological data, total antioxidant status (TAS), reactive oxygen species (ROS) production, activity of $\gamma$-glutamyltransferase $(\gamma \mathrm{GGT})$, and glucose-6-phosphate dehydrogenase were determined in the samples after rehabilitation in the investigated media.

Results. The use of C60 led to the increase of metabolic (by 1.26 times) and TAS (by 1.74 times) activities, to the decrease in the number of ROS+ cells (by 1.35 times) and to the improvement of the spermatogenic epithelium binding to the basement membrane versus control sample. Application of BSA did not significantly affect the studied biochemical indices but decreased the number of tubules with desquamation of spermatogenic epithelium in histological sections. The combined use of BSA and C60 had the best effect among investigated rehabilitation media that led to the increase of metabolic activity (by 1.51 times), TAS activity (by 1.78 times), $\gamma$ GGT activity (by 1.59 times), histostructure restoration and the decrease in the number of ROS+ cells (by 1.45 times) compared to the control samples.

Conclusions. The use of C60 and BSA combination increases the metabolic and antioxidant activity of vitrified FSTT and also has a positive effect on their histostructural characteristics compared to control samples. It should be noted that the effect of C60 and BSA addition to rehabilitation medium exceeds the results of using the investigated additives separately (by the metabolic and $\gamma$ GGT activity as well as architectonics of vitrified FSTT). These data relate to reproductive medicine and can be used to develop an effective rehabilitation protocol for vitrified FSTT.
\end{abstract}

Keywords: fullerene C60; bovine serum albumin; seminiferous tubules; vitrification.

\section{Introduction}

The rapid development of modern nanobiotechnologies leads to their application in medicine and, in particular, in reproductology. Understanding the causes of infertility contributes to the development of methods for its restoration [1]. One of them, low-temperature conservation, requires further improvement using modern biotechnologies that will provide a high level of preservation of the morphological and functional characteristics of testicular tissue. It is known that after long-term cryo- storage some reversible decrease in functional characteristics of biological objects occurs [2]. To solve this problem, rehabilitation media can be applied with the use of special admixtures.

Serum albumin is one of such rehabilitation media supplements, which is known for its powerful protective and antioxidant effects. The use of protein components helps to stabilize the strength properties of the plasma membrane, regulate osmotic pressure, maintain phospholipid fractions, buffer acid-base changes, etc. [3, 4]. Our previous studies have also shown the effectiveness of bovine 
serum albumin (BSA) using as an impurity in a cryoprotective medium for fragments of seminiferous tubules of testes (FSTT) of immature rats [5].

Along with BSA, the use of fullerenes is also of particular interest for cryobiolological purposes. This form of carbon has been actively studied in the last decades mainly because of the vast range of potential use in biomedicine. Thus, fullerene C60 found an application for the photodynamic therapy of oncological diseases as well as an antiviral and antibacterial agent. Antioxidant and antiapoptotic effects of $\mathrm{C} 60$ can be used in the therapy of neurodegenerative diseases [6]. Furthermore, fullerenes and their derivatives are also used for the creation of drugs due to the fact that carbon is the main element of biological systems that means that it is the most suitable for their modification. A distinctive feature of fullerenes and most of their derivatives is low toxicity and the ability to be excreted from the body at an acceptable rate. It should also be noted that due to their geometry and electronic structure, fullerenes are able to form compounds containing various pharmacophore groups, can easily pass into an excited state under the influence of various physical and chemical factors and enclose metal atoms inside their carbon sphere [7]. C60 can also penetrate through biological membranes, conduct protons, and interact with free radicals; these abilities are likely responsible for its protective effect. So, it can be considered as a celltargeted antioxidant worth further researching as a prospective component of novel medications [8].

However, the fullerenes and protein components have not been studied concerning the rehabilitation of FSTT of immature rats, although the development of modern biotechnological approaches to potentiation of the functional state of testicular tissue after low-temperature conservation is of interest.

In this work, we studied the efficacy of fullerene C60, bovine serum albumin (BSA), and their combination as components of rehabilitation medium of vitrified FSTT of immature rats.

\section{Materials and Methods}

The research was performed in outbreed white sexually immature (7-8 weeks aged) male rats $(n=30)$. The samples of the $2-3 \mathrm{~mm}^{3}$ in size rat testicles were obtained mechanically and exposed at $4{ }^{\circ} \mathrm{C}$ for 5 minutes sequentially in medium 1 (fibrin gel $+5 \% \mathrm{Me}_{2} \mathrm{SO}+6 \%$ glycerol $+0.1 \mathrm{M}$ sucrose) and medium 2 (fibrin gel $+15 \% \mathrm{Me}_{2} \mathrm{SO}$ $+18 \%$ glycerol $+0.5 \mathrm{M}$ sucrose), then vitrified by rapid immersion into liquid nitrogen $[9,10]$. The thawing was carried out in $1 \mathrm{M}$ sucrose at $50^{\circ} \mathrm{C}$ with a successive transfer of samples to solutions of decreasing sucrose concentration $(0.5 \mathrm{M}, 0.25 \mathrm{M}, 0 \mathrm{M})$ at $22{ }^{\circ} \mathrm{C}$ [11]. Vitrified-thawed samples of FSTT were incubated $\left(22^{\circ} \mathrm{C}\right)$ for $30 \mathrm{~min}$ in Leibovitz's medium with addition of $15 \mu \mathrm{g} / \mathrm{mL}$ C60, $5 \mathrm{~g} / \mathrm{L}$ BSA or combination of $15 \mu \mathrm{g} / \mathrm{mL}$ C60 with $5 \mathrm{~g} / \mathrm{L}$ BSA (C60+BSA). We used an aqueous suspension of unmodified fullerene C60 (prod. no. 572500, SigmaAldrich, USA). A typical colloidal solution of C60 was obtained immediately before use by the transfer of these nanoparticles from toluene to water, followed by sonication [12]. Control samples were incubated in the medium without C60 or BSA addition. MTT test, histomorphological data, total antioxidant status (TAS), reactive oxygen species (ROS) production, activity of $\gamma$-glutamyltransferase $(\gamma \mathrm{GGT})$ and glucose-6-phosphate dehydrogenase (G6PD) were determined in the samples after rehabilitation in the investigated media. The scheme of the experiment is shown in Fig. 1.

MTT [3-(4,5-dimethylthiazol-2-yl)-2,5-diphenyltetrazolium bromide] (Fluka, Germany) at the final concentration of $0.5 \mathrm{mg} / \mathrm{mL}$ was added to the samples of FSTT and after three-hour incubation at $37^{\circ} \mathrm{C}$ was removed with $100 \%$ DMSO addition to solubilize formazan. Absorbance was read at $570 \mathrm{~nm}$ (CHEM 7, ERBA, Czech Republic) and calculated per $1 \mathrm{mg}$ of tissue.

The samples were homogenized, filtered, and then centrifugated for $10 \mathrm{~min}(1000 \mathrm{~g})$. In supernatant TAS, yGGT and G6PD activity was evaluated quantitatively by UV spectrophotometry (CHEM 7, ERBA, Czech Republic) using test kits (Randox, UK) according to the instructions and calculated per $1 \mathrm{mg}$ of protein.

Enzymatic disaggregation method was used to obtain cell suspension from FSTT: the samples were incubated with $0.25 \%$ trypsin for $30 \mathrm{~min}$ at $37^{\circ} \mathrm{C}$, filtered, and then centrifugated for $10 \mathrm{~min}$ $(1000 \mathrm{~g})$. The ROS production was studied quantitatively by the cytofluorimetric method (FACS Calibur, Becton Dickinson, USA) using test kit (Sigma-Aldrich, USA). Obtained data were processed with WinMDI v.2.8 software.

Histomorphology study was performed by a person who did not know the details of the experiment. The slices ( $7 \mu \mathrm{m}$ thickness) were prepared from paraffin blocks and stained with hematoxylin and eosin. Sections were studied using Axio Observer Z1 inverted microscope (Carl Zeiss, Germany); obtained images were processed using the ZEISS ZEN 2 (Carl Zeiss). The following parameters were 


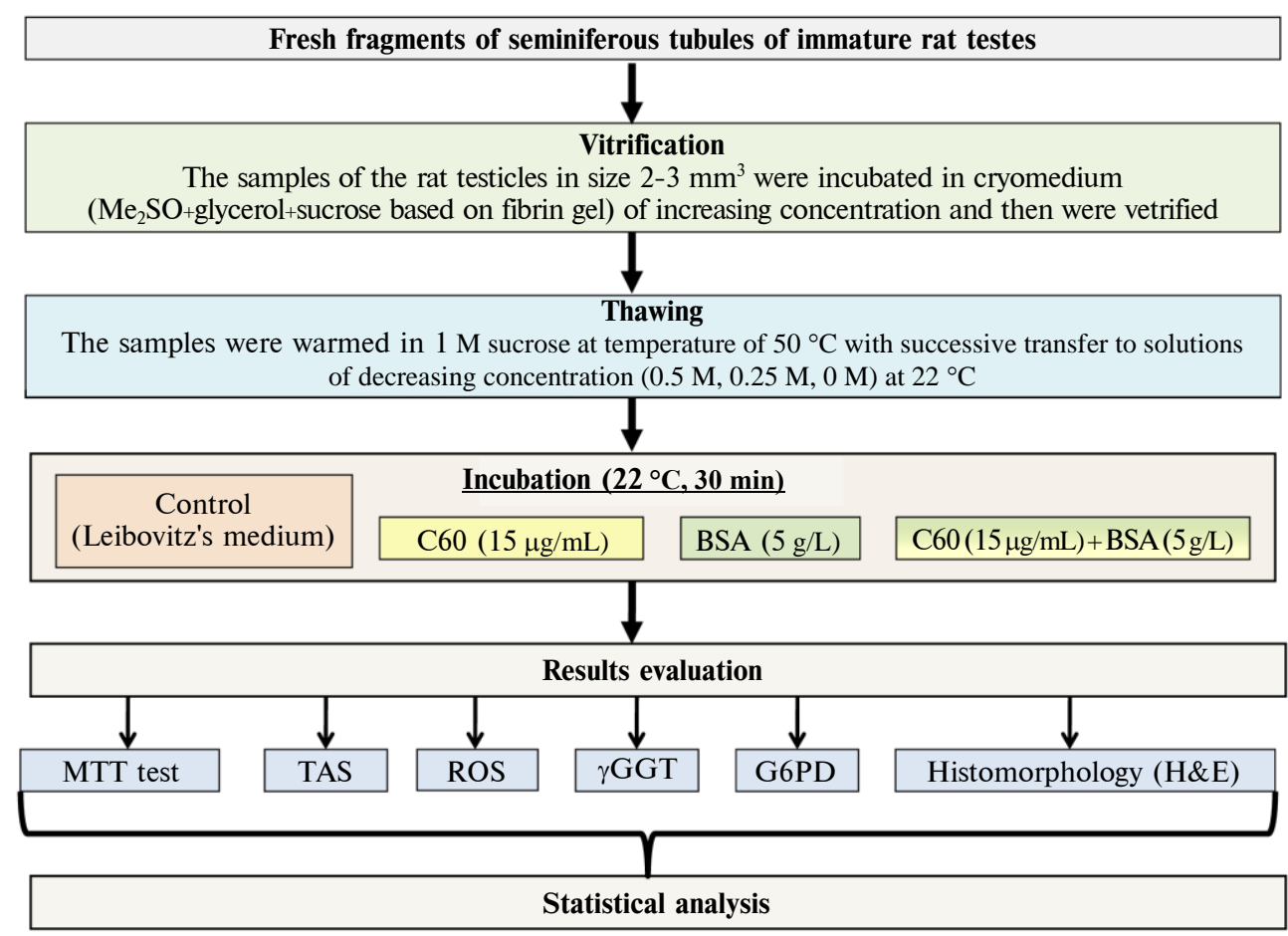

Figure 1: Experimental scheme. TAS - total antioxidant status, ROS - reactive oxygen species production, yGGT - activity of $\gamma$-glutamyltransferase, G6PD - activity of glucose-6-phosphate dehydrogenase, BSA - bovine serum albumin, H\&E - hematoxylin and eosin staining

evaluated: retraction of cells, condensation of nuclei, formation of cracks in the spermatogenic layer, desquamation of the epithelium, condition of a lamina propria. The total cell density of spermatogenic epithelium was also evaluated by counting a nuclei number per $1 \mathrm{~mm}^{2}$.

The results were statistically processed with the Kruskal-Wallis ANOVA test with multiple comparisons.

All the manipulations with animals were carried out in accordance with international bioethical norms, legislative documents of Ukraine, statements of the IV European Convention for the Protection of Vertebrate Animals Used for Experimental and Other Scientific Purposes as well as the protocol of the Committee in Bioethics of the Institute for Problems of Cryobiology and Cryomedicine of the National Academy of Sciences of Ukraine (No. 2014-02).

\section{Results}

The obtained results of metabolic activity and total cell density in vitrified FSTT samples after incubation in the studied media are graphically represented in Fig. 2.

The BSA use did not lead to significant changes in metabolic activity (Fig. 2a). The 1.26- fold increase of metabolic activity $(p<0.05)$ was indicated in the samples rehabilitated in the medium with $\mathrm{C} 60$ relative to the control. This index was higher by 1.51 and 1.2 times $(p<0.05)$ for samples rehabilitated with the combination of C60 with BSA relative to the control and $\mathrm{C} 60$ group respectively. Increasing MTT test result for C60 and its combination with BSA indicates a good protective activity of these substances for preservation of cells in vitrified testicular tissue. However, the most pronounced effect on metabolic activity was observed after incubation with combination C60 and BSA.

According to the results of total cell density measuring in the spermatogenic epithelium, it can be concluded that the addition of C60, BSA and C60+BSA combination to the incubation medium was effective for vitrified FSTT, significantly increasing this parameter relative to the control by 1.6 , 1.3 and 1.7 times respectively $(p<0.05)$ (Fig. 2b). It can be concluded that despite the absence of statistically significant difference in cell density between the groups $\mathrm{C} 60$ and C60+BSA, their metabolic activity was higher under the use of investigated combination (C60+BSA).

The next stage of our work was the investigation of fullerene C60 and BSA effects on histomorphological parameters of vitrified FSTT of immature rats. The obtained results are shown in Fig. 3. 

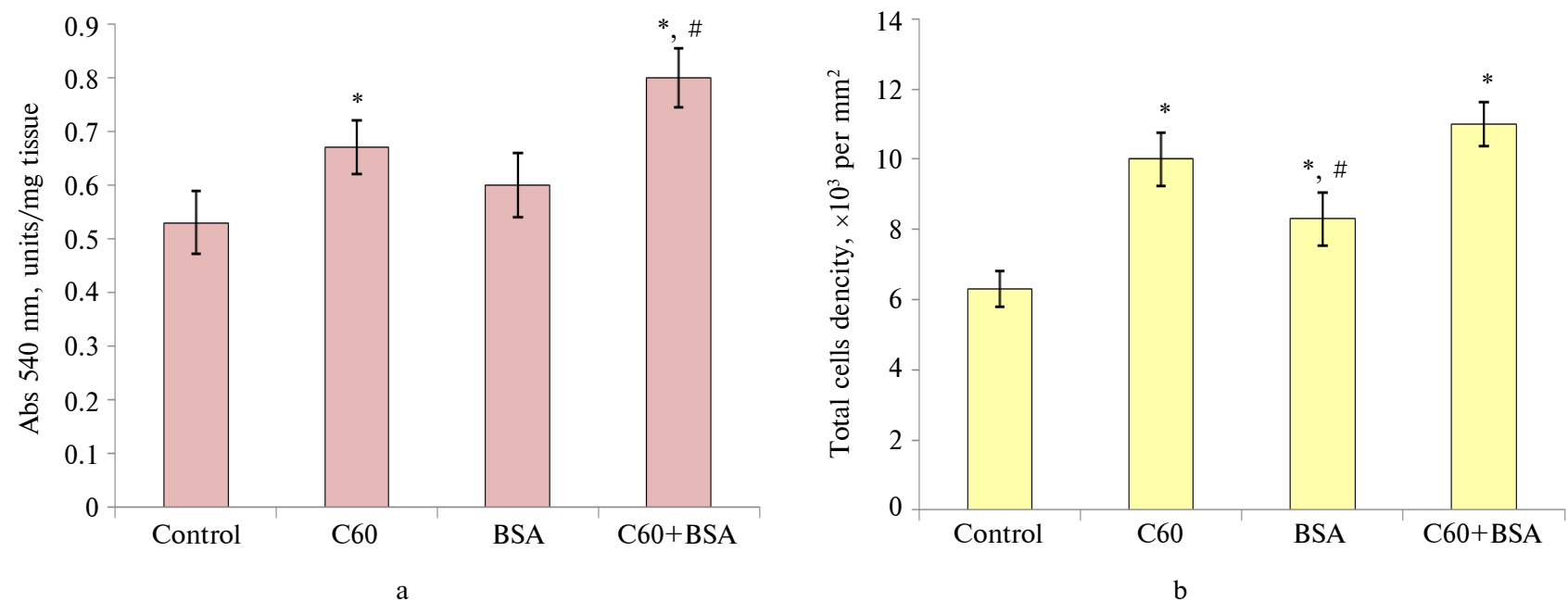

Figure 2: Effect of incubation in the media with C60 and bovine serum albumin (BSA) on (a) metabolic activity (MTT test) and (b) total cell density of spermatogenic epithelium in vitrified fragments of seminiferous tubules of testes; * - the difference is statistically significant relative to the control $(p<0.05),{ }^{*}-$ the difference is statistically significant relative to the group C60 $(p<0.05)$

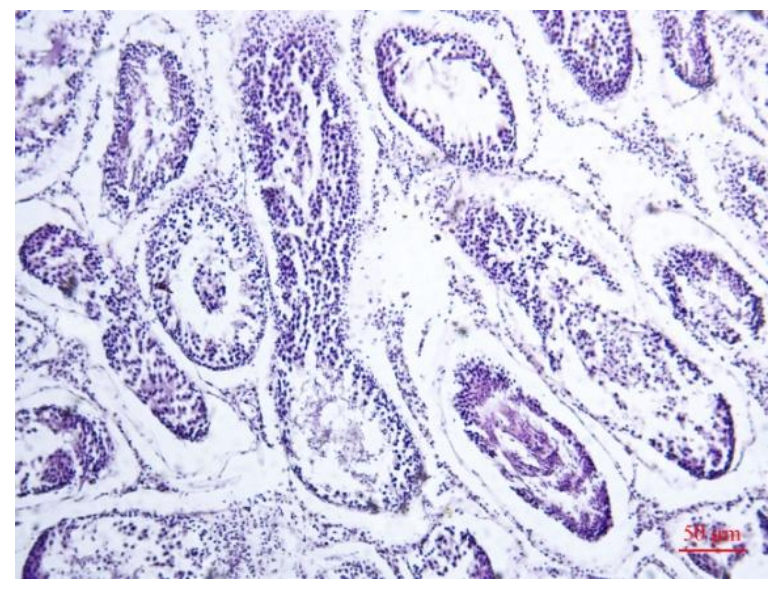

a

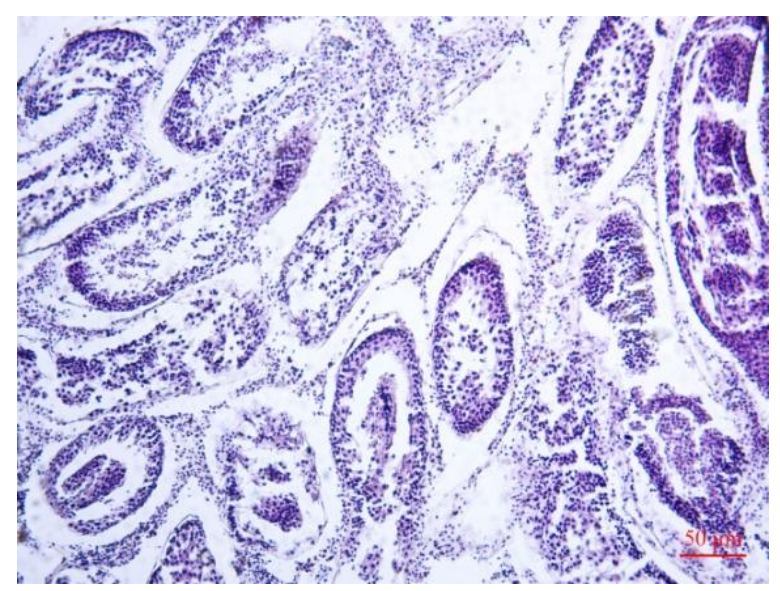

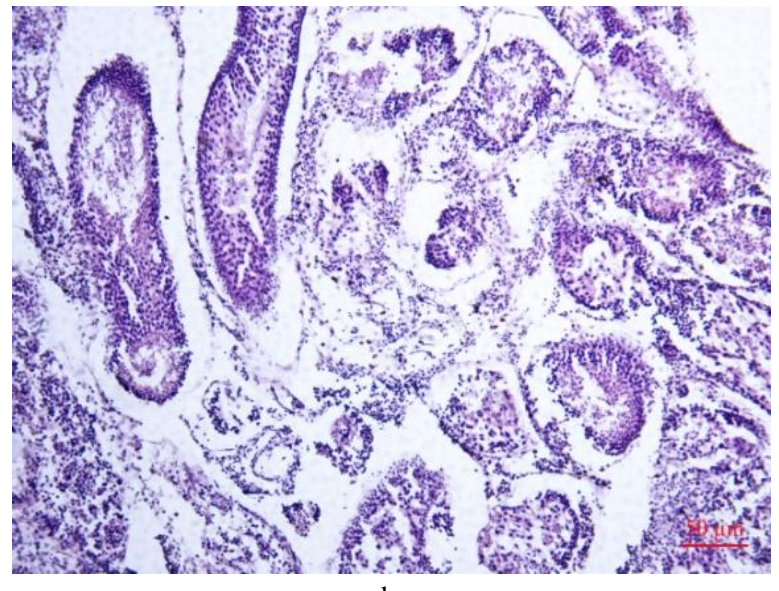

b

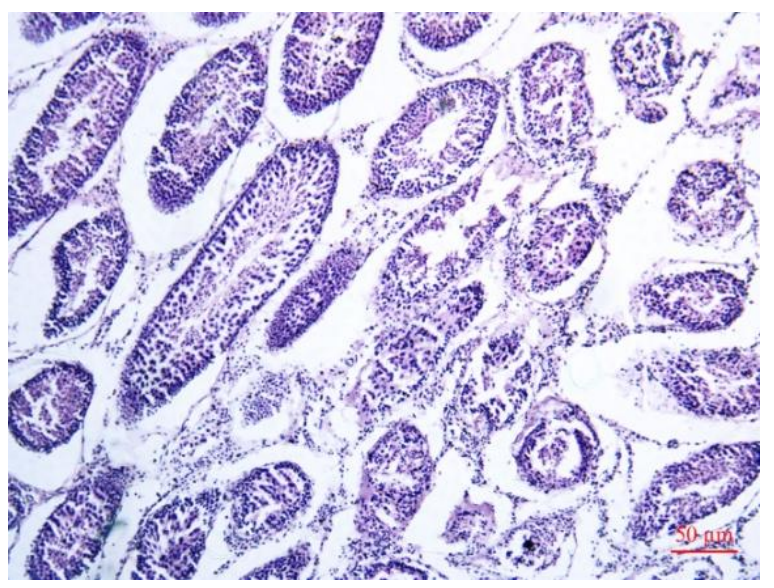

d

Figure 3: Morphological characteristics of vitrified fragments of seminiferous tubules of testes incubated in media: (a) control group; (b) C60; (c) bovine serum albumin; (d) C60 + bovine serum albumin. Hematoxylin and eosin staining 
The most extensive histological damage was observed in the control group including moderate alterations of the epithelial layer with the formation of cracks resulted in disruption of cell-cell contacts and cell detachment from the basement membrane. The latter looked thickened and edematous. The use of C60 led to improvement in the epithelium binding to the basement membrane and its condition compared to the control; BSA decreased the number of tubules with desquamation of germ cells in histological sections. Also, C60+BSA combination improved maintenance of tubule architecture with minimal epithelial detachment after the 30-min incubation. It should be noted that the presence of cracks inside the wall of the seminiferous tubules in this group did not lead to disruption of intercellular contacts. Intimate contact between the basement membrane and the cells of the spermatogenic epithelium is important for intercellular interactions and delivery of nutrients for germ cell growth and differentiation into the tubules [13]. In sum, it can be concluded that combined use of C60 and BSA maintained morphology of vitrified FSTT better compared to their application separately.

The results of TAS activity and ROS + cell content in vitrified FSTT after the incubation in the studied media are presented in Table 1.

The C60 use increased TAS activity (by 1.74 times) and decreased the number of ROS + cells (by 1.35 times) compared to the control $(p<0.05)$. The application of BSA did not change significantly these parameters versus control. And C60+BSA combination use led to a 1.78-fold increase of TAS activity, a 1.45 -fold decrease in the number of ROS + cells compared to the control $(p<0.05)$ and did not differ from group C60.

The data of $\gamma$ GGT and G6PD activities in vitrified FSTT after the incubation in the studied media are represented in Table 2.

Table 1: TAS activity and content of ROS+ cells in vitrified fragments of seminiferous tubules of testes after the incubation in the media with C60 and BSA

\begin{tabular}{lcc}
\hline \multicolumn{1}{c}{ Sample } & $\begin{array}{c}\text { TAS, } \\
\mathrm{mM} / \mathrm{mL} / \mathrm{mg} \\
\text { protein }\end{array}$ & ROS,$+ \%$ \\
\hline Control & $15.62 \pm 1.54$ & $4.42 \pm 0.25$ \\
C60 & $27.14 \pm 1.78^{1}$ & $3.24 \pm 0.31^{1}$ \\
BSA & $16.05 \pm 2.16^{2}$ & $4.05 \pm 0.29^{2}$ \\
C60+BSA & $27.92 \pm 1.82^{1}$ & $3.05 \pm 0.37^{1}$ \\
\hline Notes. TAS - total antioxidant status, ROS - reactive oxygen \\
species, BSA - bovine serum albumin; ${ }^{1}-$ the difference is \\
statistically significant relative to the control $(p<0.05),{ }^{2}-$ \\
the difference is statistically significant relative to the group \\
C60 $(p<0.05)$.
\end{tabular}

The analysis of the results showed an increase of $\gamma \mathrm{GGT}$ activity by 1.32 (C60) and 1.59 times (C60+BSA) in vitrified FSTT compared to the control. The use of BSA did not affect investigated parameter. The activity of $\gamma$ GGT was increased by 1.2 times $(\mathrm{C} 60+\mathrm{BSA})$ in vitrified FSTT compared to the group C60. Incubation of vitrified FSTT in all investigated media did not affect G6PD activity compared to the control.

\section{Discussion}

The fields of application of fullerenes are very diverse. This is due to the fact that the structure of fullerene, which looks like a soccer ball, absorbs everything that is desirable to be placed there, from a part of the genetic code, vitamins, medicines to various gases. Fullerenes have an amazing ability to integrate into the surfaces of cell membranes. They are not only unique antioxidants, but also unique transports of various substances, which allow them to be used in a wide variety of scientific and practical fields. Physicians and biologists use fullerenes as a way to deliver various drugs, antibiotics, hormones, and even genes into cells. Also, chemical experiments with fullerenes working as catalysts as well as adsorbents of a new type show excellent results. Among the antioxidants known to date, fullerenes, or rather, their aqueous solutions are the most powerful, although their mechanisms of action are fundamentally different from those of conventional antioxidants. They act even in ultra-low doses and their effect even after a single dose lasts for months. Fullerenes are qualitatively superior to all other antioxidants in terms of strength and duration of action. They have different mechanisms of action. Whereas classical antioxidants are reducing agents that are consumed during the reaction, fullerenes are catalysts for recombination and the mutual destruction of free radicals and are not consumed at all [7, 8].

Table 2: $\gamma$ GGT and G6PD activities in vitrified fragments of seminiferous tubules of testes after the incubation in the media with $\mathrm{C} 60$ and BSA

\begin{tabular}{lcc}
\hline Sample & $\begin{array}{c}\text { vGGT, } \\
\text { units/L/mg } \\
\text { protein }\end{array}$ & $\begin{array}{c}\text { G6PD, } \\
\text { units/L/mg } \\
\text { protein }\end{array}$ \\
\hline Control & $3.92 \pm 0.52$ & $47.12 \pm 1.93$ \\
C60 & $5.19 \pm 0.61^{1}$ & $49.24 \pm 2.07$ \\
BSA & $4.07 \pm 0.37^{2}$ & $45.05 \pm 2.35$ \\
C60+BSA & $6.25 \pm 0.49^{1,2}$ & $46.05 \pm 1.85$ \\
\hline
\end{tabular}

Notes. $\gamma$ GGT - activity of $\gamma$-glutamyltransferase, G6PD activity of glucose-6-phosphate dehydrogenase; BSA - bovine serum albumin; ${ }^{1}-$ the difference is statistically significant relative to the control $(p<0.05),{ }^{2}-$ the difference is statistically significant relative to the group $\mathrm{C} 60(p<0.05)$. 
The over ROS formation occurs during cryopreservation, leading to decrease antioxidant systems activity [14]. The results of our work showed that incubation of vitrified FSTT with C60 and C60+BSA led to a decrease in the relative number of ROS+ cells. Increasing TAS activity is probably related to the pronounced antioxidant action of fullerene C60 that is a powerful free radical scavenger. In the work of authors [15], this antioxidant property is based on the fact that C60 has a large content of conjugated double bonds and lowlying lowest unoccupied molecular orbital that can freely take up an electron that makes interaction of radicals possible. Thus, the fullerene can react with many superoxides without being consumed.

It is known that the main enzymes involved in the antioxidant defense system are: superoxide dismutase, catalase and glutathione peroxidase. However, many others, so-called "indirect" antioxidant enzymes, also participate in the processes of ROS neutralization due to the involvment in biosynthesis/recycling of thiols or excretion of oxidized secondary metabolites. So GGT is responsible for maintaining the constant level of the most abundant redox scavenging molecule - glutathione, uptaking it from the extracellular fluid into the cells $[16,17]$. In the seminal tubules this enzyme is localized in Sertoli cells. GGT is considered a marker of Sertoli cell function and is stimulated by appropriate hormones. In the study [16], GGT was shown to be present in epididymal epithelial cells and fluid lumen. It has been suggested that epididymal GGT may play a role in oxidant protection of sperm in the epididymal duct and/or in restoring extracellular cysteine for the synthesis of epididymal proteins. G6PD is the NADPH-producing enzyme in nucleated cells. The overexpression of G6PDH increased resistance to ROS-induced cell death [18] and maintained intracellular glutathione stores increasing the activity of glutathione reductase [19]. Thus, some authors indicated G6PD and GGT as important enzymes involved in the antioxidant defense of the cell.

To assess the metabolic activity of cells we used a colorimetric MTT test based on the ability of NADPH-dependent oxidoreductase enzymes to display the number of viable cells. Increasing MTT test result for C60 fullerene groups indicates good preservation of cells in rehabilitated FSTT that is also consistent with the results of the histomorphological study. Thus, the histological examination showed a decrease in detachment of spermatogenic epithelium from basement membrane and an increase of average cell density. It is necessary to emphasize the importance of relationship preservation between spermatogenic epithelium and basement membrane because the basement membrane in the testis serves as a reservoir of uniquely important cytokines for maintenance of tight junctions [13]. The use of BSA did not affect the metabolic and antioxidant activity but decreased the number of tubules with desquamation of spermatogenic epithelium in histological sections. The combined use of BSA and C60 had the best effect among investigated rehabilitation media leading to an increase in the functional activity and to histological structure preservation of vitrified FSTT.

Cryopreservation by vitrification is increasingly used at the freezing of reproductive cells and tissue. During slow cooling, the elements of the testicular tissue are damaged by intracellular ice crystals and the ones formed in extracellular space. Vitrification is an effective method to preclusion the formation of ice crystals due to the use of high concentrations of cryoprotectants and ultra-fast cooling that minimizes cell damage [20]. Thus, for the rehabilitation of seminiferous tubule fragments of the immature rats, it is possible to use multicomponent media in which the solution is enriched by biopolymer and nanoparticles.

\section{Conclusions}

The use of combination of C60 and BSA promotes the increase of metabolic activity of vitrified FSTT by 1.51 times $(p<0.05)$, TAS activity by 1.78 times $(p<0.05), \gamma$ GGT by 1.59 times $(p<0.05)$, histostructure restoration and the decrease in the number of ROS + cells by 1.45 times $(p<0.05)$ compared to the control samples. It should be noted that the effect of C60 and BSA addition to rehabilitation medium exceeds the results of using the investigated additives separately (by the metabolic and $\gamma$ GGT activity as well as architectonics of vitrified FSTT). These results can be used for justification and elaboration of effective rehabilitation methods for vitrified fragments of seminiferous tubules of testes using the combination of biopolymers and nanoparticles.

\section{Funding}

This work was supported by the program of the National Academy of Science of Ukraine "Support for the development of priority areas of scientific research" (code 6541230), contract number 2.2.6.130. 


\section{References}

[1] Song Y, Sharp R, Lu F, Hassan M. The future potential of cryopreservation for assisted reproduction. Cryobiology. 2010;60(3):S60-5. DOI: 10.1016/j.cryobiol.2009.09.009

[2] Finkel T, Holbrook NJ. Oxidants, oxidative stress and the biology of ageing. Nature. 2000;408(6809):239-47. DOI: $10.1038 / 35041687$

[3] De Leeuw FE, De Leeuw AM, Den Daas JH, Colenbrander B, Verkleij AJ. Effects of various cryoprotective agents and membrane-stabilizing compounds on bull sperm membrane integrity after cooling and freezing. Cryobiology. 1993;30(1):32-44. DOI: $10.1006 /$ cryo.1993.1005

[4] Dobretsov GYe. Fluorescent probes in the study of cells, membranes and lipoproteins. Moscow: Nauka; 1989. 277 p.

[5] Volkova NO, Yukhta MS, Chernyshenko LG, Stepanyuk LV, Sokol LV, Goltsev AM. Exposure of seminiferous tubules of immature rats to cryoprotective media of various compositions. Problems Cryobiol Cryomed. 2017;27(3):203-18. DOI: $10.15407 /$ cryo27.03.203

[6] Ritter U, Prylutskyy YI, Evstigneev MP, Davidenko NA, Cherepanov VV, Senenko AI, et al. Structural features of highly stable reproducible $\mathrm{C} 60$ fullerene aqueous colloid solution probed by various techniques. Fuller Nanotub Carbon Nanostruct. 2014;23(6):530-4. DOI: 10.1080/1536383X.2013.870900

[7] Fazylov SD, Nurkenov OA, Muldakhmetov ZM, Gazaliev AM, Arinova AE, Ibraev MK, et al. Biologically active derivatives of fullerene C60. Current state and development prospects. Bulletin of the Karaganda University. 2020;99:11-20. DOI: $10.31489 / 2020 \mathrm{Ch} 3 / 11-20$

[8] Emelyantsev S, Prazdnova E, Chistyakov V, Alperovich I. Biological effects of C60 fullerene revealed with bacterial biosensor-toxic or rather antioxidant? Biosensors (Basel). 2019;9(2):81. DOI: 10.3390/bios9020081

[9] Volkova N, Yukhta M, Goltsev A. Biopolymer gels as a basis of cryoprotective medium for testicular tissue of rats. Cell Tissue Bank. 2018;19(4):819-26. DOI: 10.1007/s10561-018-9740-Z

[10] Volkova NO, Yukhta MS, Goltsev AM. Vitrification of rat testicular tissue using biopolymers. Biopolym Cell. 2020;36(2):122-32. DOI: $10.7124 / \mathrm{bc} .000 \mathrm{~A} 26$

[11] Volkova N, Yukhta M, Sokil L, Chernyshenko L, Stepaniuk L, Goltsev A. Determination of warming modes for seminiferous tubules of rat's testes after vitrification. Problems Cryobiol Cryomed. 2021;31(1):95-9. DOI: 10.15407/cryo31.01.095

[12] Scharff P, Ritter U, Matyshevska OP, Prylutska SV, Grynyuk II, Golub AA, et al. Therapeutic reactive oxygen generation. Tumori. 2008;94(2):278-83.

[13] Siu MK, Cheng CY. Extracellular matrix: recent advances on its role in junction dynamics in the seminiferous epithelium during spermatogenesis. Biol Reprod. 2004;71(2):375-91. DOI: 10.1095/biolreprod.104.028225

[14] Bakry R, Vallant RM, Najam-ul-Haq M, Rainer M, Szabo Z, Huck CW, et al. Medicinal applications of fullerenes. Int J Nanomed. 2007;2(4):639-49.

[15] Turner TT, Lysiak JJ. Oxidative stress: a common factor in testicular dysfunction. J Androl. 2008;29(5):488-98. DOI: $10.2164 /$ jandrol.108.005132

[16] Domínguez-Vías G, Segarra AB, Martínez-Cañamero M, Ramírez-Sánchez M, Prieto I. Influence of a virgin olive oil versus butter plus cholesterol-enriched diet on testicular enzymatic activities in adult male rats. Int J Mol Sci. 2017;18(8):1701. DOI: $10.3390 /$ ijms 18081701

[17] Karp DR, Shimooku K, Lipsk PE. Expression of gamma-glutamyl transpeptidase protects ramos B cells from oxida-tioninduced cell death. J Biol Chem. 2001;276:3798-804. DOI: 10.1074/jbc.M008484200

[18] Tian WN, Braunstein LD, Apse K, Pang J, Rose M, Tian X, et al. Importance of glucose-6-phosphate dehydro-genase activity in cell death. Am J Physiol. 1999;276:1121-31. DOI: 10.1152/ajpcell.1999.276.5.C1121

[19] Leopold JA, Zhang YY, Scribner AW, Stanton RC, Loscalzo J. Glucose-6-phosphate dehydrogenase overexpression decreases endothelial cell oxidant stress and increases bioavailable nitric oxide. Arterioscler Thromb Vas Biol. 2003;23:411 -7. DOI: 10.1161/01.ATV.0000056744.26901.BA

[20] Poels J, Langendonckt A, Many MC, Wese FX, Wyns C. Vitrification preserves proliferation capacity in human spermatogonia. Hum Reprod. 2013;28(3):578-89. DOI: 10.1093/humrep/des455 


\section{Н.О. Волкова, М.С. Юхта, Л.В. Сокіл, Л.Г. Чернишенко, Л.В. Степанюк, А.М. Гольцев}

Інститут проблем кріобіології і кріомедицини Національної академії наук України, Харків, Україна

\section{ЕФЕКТИВНІСТЬ КОМБІНОВАНОГО ЗАСТОСУВАННЯ ФУЛЕРЕНУ С6О І БИЧАЧОГО СИРОВАТКОВОГО АЛЬБУМІНУ ДЛЯ РЕАБІЛІТАЦІЇ ВІТРИФІКОВАНИХ ФРАГМЕНТІВ НЕЗРІЛИХ КАНАЛЬЦІВ СІМ'ЯНИКІВ}

Проблематика. На сьогодні кріоконсервовані репродуктивні тканини використовуються для лікування деяких форм безпліддя у чоловіків. Однак після довготривалого збереження фрагментів звитих канальців сім'яників (ФЗКС) в умовах низькотемпературного банку $\left(-196^{\circ} \mathrm{C}\right)$ відбувається зворотне зниження їх морфологічних та функціональних характеристик. Для вирішення цієї проблеми після заморожування-відігріву перспективним є використання реабілітаційних середовищ із застосуванням спеціальних добавок. Завдяки потужним захисним і антиоксидантним властивостям сироваткового альбуміну та фулерену С60 їх застосування дає змогу стабілізувати плазматичну мембрану, осмотичний тиск, знизити вміст вільних радикалів, що робить їх перспективними кандидатами для використання в розробці середовищ реабілітації біологічних об'єктів після кріоконсервування.

Мета. У роботі вивчали ефективність використання фулерену С60, бичачого сироваткового альбуміну (БСА) та їх комбінації як складових середовища реабілітації вітрифікованих ФЗКС статевонезрілих щурів.

Методика реалізації. Зразки ФЗКС після вітрифрікації-відігріву інкубували $\left(22{ }^{\circ} \mathrm{C}\right)$ протягом 30 хв у середовищі Лейбовіца 3 додаванням 15 мкг/мл С60, 5 г/л БСА або їх комбінації. Контрольні зразки інкубували в середовищі без додавання С60 або БСА. Метаболічну активність (МТT-тест), гістоморфологічні дані, загальний антиоксидантний статус (TAS), продукцію активних форм кисню (ROS), активність $\gamma$-глутамілтрансферази ( $\gamma Г \Gamma T)$ та глюкозо-6-фоссфатдегідрогенази визначали у зразках після реабілітації в досліджуваних середовищах.

Результати. Застосування C60 привело до збільшення метаболічної (в 1,26 разу) та TAS (у 1,74 разу) активностей, до зменшення кількості ROS+ клітин (у 1,35 разу) та до покращення зв'язування сперматогенного епітелію з базальною мембраною порівняно з контролем. Застосування БСА істотно не впливало на досліджувані біохімічні показники, але зменшило кількість канальців із десквамацією сперматогенного епітелію в гістологічних зрізах. Спільне застосування БСА та С60 мало найкращий ефект серед досліджуваних реабілітаційних середовищ, що приводило до збільшення метаболічної активності (в 1,51 разу), ак-

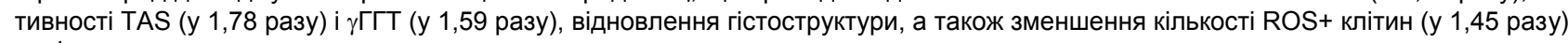
порівняно з контрольними зразками.

Висновки. Застосування комбінації С60 та БСА підвищує метаболічну й антиоксидантну активність вітрифікованих ФЗКС, а також позитивно впливає на їх гістоструктуру порівняно з контрольними зразками. Слід зазначити, що ефект додавання С60 і БСА до реабілітаційного середовища перевищує результати окремого використання досліджуваних добавок (за метаболічною та үГГТ активністю, а також результатами гістологічного дослідження). Ці дані відносяться до репродуктивної медицини і можуть бути використані для розробки ефективного протоколу реабілітації вітрифікованих ФЗКС.

Ключові слова: фулерен С60; бичачий сироватковий альбумін; звиті канальця; вітрифікація.

\section{Н.А. Волкова, М.С. Юхта, Л.В. Сокол, Л.Г. Чернышенко, Л.В. Степанюк, А.Н. Гольцев}

Институт проблем криобиологии и криомедицины Национальной академии наук Украины, Харьков, Украина

\section{ЭФФЕКТИВНОСТЬ КОМБИНИРОВАННОГО ПРИМЕНЕНИЯ ФУЛЛЕРЕНА С6О И БЫЧЬЕГО СЫВОРОТОЧНОГО АЛЬБУМИНА ДЛЯ РЕАБИЛИТАЦИИ ВИТРИФИЦИРОВАННЫХ ФРАГМЕНТОВ НЕЗРЕЛЫХ КАНАЛЬЦЕВ СЕМЕННИКОВ}

Проблематика. На сегодняшний день криоконсервированные репродуктивные ткани используются для лечения некоторых форм бесплодия у мужчин. Однако после длительного хранения фрагментов извитых канальцев семенников (ФИКС) в условиях низкотемпературного банка $\left(-196{ }^{\circ} \mathrm{C}\right)$ происходит обратимое снижение их морфологических и функциональных характеристик. Для решения этой проблемы после замораживания-отогрева перспективным является использование реабилитационных сред с применением специальных добавок. Благодаря мощным защитным и антиоксидантным свойствам сывороточного альбумина и фуллерена С60 их применение позволяет стабилизировать плазматическую мембрану, осмотическое давление, снизить содержание свободных радикалов, что делает их перспективными кандидатами для использования в разработке сред реабилитации биологических объектов после криоконсервирования.

Цель. В работе изучали эффективность использования фуллерена С60, бычьего сывороточного альбумина (БСА) и их комбинации как составляющих среды реабилитации витрифицированных ФИКС неполовозрелых крыс.

Методика реализации. Образцы ФИКС после витрификации-отогрева инкубировали $\left(22^{\circ} \mathrm{C}\right)$ в течение 30 мин в среде Лейбовица с добавлением 15 мкг/мл С60, 5 г/л БСА или их комбинации. Контрольные образцы инкубировали в среде без добавления С60 или БСА. Метаболическую активность (МТТ-тест), гистоморфологические данные, общий антиоксидантный статус (TAS), продукцию активных форм кислорода (ROS), активность $\gamma$-глутамилтрансферазы ( $\gamma$ ГГT) и глюкозо-6-фоссратдегидрогеназы определяли в образцах после реабилитации в исследуемых средах.

Результаты. Применение С60 приводило к увеличению метаболической (в 1,26 раза) и TAS (в 1,74 раза) активностей, к уменьшению количества ROS+ клеток (в 1,35 раза) и к улучшению связывания сперматогенного эпителия с базальной мембраной по сравнению с контролем. Применение БСА существенно не влияло на исследуемые биохимические показатели, но уменьшало количество канальцев с десквамацией сперматогенного эпителия в гистологических срезах. Совместное применение БСА и С60 имело наилучший эффект среди исследуемых реабилитационных сред, что приводило к увеличению метаболической активности (в 1,51 раза), активности TAS (в 1,78 раза) и үГГТ (в 1,59 раза), восстановлению гистоструктуры, а также уменьшению количества ROS+ клеток (в 1,45 раза) по сравнению с контрольными образцами.

Выводы. Применение комбинации С60 и БСА повышает метаболическую и антиоксидантную активности витрифицированных ФИКС, а также положительно влияет на их гистоструктуру по сравнению с контрольными образцами. Следует отметить, что эффект добавления С60 и БСА в реабилитационную среду превышает результаты отдельного использования исследуемых


относятся к репродуктивной медицине и могут быть использованы для разработки эффективного протокола реабилитации витрифицированных ФИКС.

Ключевые слова: фуллерен С60; бычий сывороточный альбумин; семенные канальца; витрификация. 